At the present time there are some schemes on foot to provide London with what might be called a conference centre which among other things would contain auditoria in which individual scientific societies could hold their meetings if they so desired and which would be invaluable for international gatherings. These schemes vary from the grandiose to the inadequate, but it is possible that if all scientific societies could agree to support the idea of a building in the nature of a conference centre something might be accomplished. This matter is under consideration by the officers.

In an ancient society it is perhaps easier to look backwards than forwards, but in the rapidly changing world in which we live it becomes urgent to adapt ourselves to the prevailing scientific environment. Perhaps new and elegant accommodation will give us a base from which the Society can move forward into the exciting times that await us.

As Fellows can see from the annual report of Council, the activities of the Society have been maintained and indeed they have had to be increased in view of the turmoil surrounding the reorganization of science and technology. This has thrown a great burden on the secretaries in particular. It is with regret that we part with an able, umusing and onergetic biological secretary, Sir Lindor Brown. I am grateful to him, for he has been of the greatest assistance to me porsonally and has, on many occasions, propped me up when I clearly did not know what I was doing. He has served the Society not only by his wise advice in its internal affairs, but also by acting as its representative on many external bodies. The surviving officers will all miss him and not least for the anecdotes with which he has cheered us up from time to time.

The work of the secretaries has been somewhat lightened by the so-called active vice-presidents. Sir Gordon Sutherland has held this office for two years and is now retiring. He has been of very great help to us and particularly in directing attention, through his Committee on Emigration, to the seriousness of the loss of our scientists and technologists. I would like now to thank him for all he has done for the Society and for science in a wider context.

It remains only for me to welcome the new biological secretary, who is just beginning to realize the strenuous nature of his new office; but he is, I am happy to say, a very vigorous man [Nature, 200, 1049; 1963].

No year can close without recording our continued indebtedness to the Executive Secretary for his unremitting labours on behalf of the Society and its manifold interests. $\mathrm{He}$ is backed by an able and well-informed staff, and to them also we give our sincere thanks.

With the blurring of the conception of the British Commonwealth one of the functions of the Society, which may become more important with the passage of time, is to soe that our close associations with actively growing and sympathetic countries are fostered in every possible way. In this connexion, the Executive Secretary paid a visit to New Zealand in August and $I$ joined him in Australia. I need scarcely say that we were both treated with unbounded hospitality and that our glimpses of antipodean scientific activities were greatly stimulating. We hope that the close contacts we have with the Australian Academy may be strengthened by visits of a similar character at not too infrequent intervals.

\title{
OBITUARIES
}

\section{Prof. F. E. Zeuner}

Prof. F. E. Zeuner, head of the Department of Environmental Archæology in tho University of London Institute of Archæology, died on November 5 at the age of fifty-eight.

Zeuner came to London from Germany in 1933. $\mathrm{H}_{\theta}$ joined the staff of the British Museum (Natural History) us a research associate in palæontology in 1934 and, with the aid of a Levorhulme studentship of the London Museum, also worked on the problems of the Quaternary deposits of the Thames Valley. The results of this work were later incorporated in The Pleistocene Period, first published by the Ray Society in 1945. In 1937 he joined the newly founded Institute of Archæology, then establishod in St. John's Lodge, Regent's Park, as honorary lecturer in geochronology, and thus established on a systematic basis the study of human environment in the past as it had not previously been attempted. After the Second World War (in which he workod with the locust control unit at South Kensington) Zeuner's was one of two chairs created by the University when it accopted full responsibility for the Institute, the term "environmental archæology' being substituted for geochronology.

Zeuner's breadth of interest was already apparent before he left Germany as a young man, and he maintained and developed this throughout his career. $\mathrm{H}_{\theta}$ visited many parts of the world in pursuit of his subject, usually returning with material which then became the subject of research undertaken by himself or by his students. He was associated with many foreign learned societies and institutions, and as a result of his many contacts -he was, incidentally, a good linguist-had built up a collection of separates which was invaluable to his students, who were allowed free access to it. Although at times the centre of controversy, his best-known book, Dating the Past, demonstrates his grasp of the environmental sciences. Tts fourth edition appeared in 1958 and it has been translated into a number of foreign languages. Among his other activities, for several years ho directed the operation of the carbon-14 dating apparatus which the Royal Institution set up and maintained in Albemarle Street. It was this machine, which was functioning at a time when others in Britain were having difficulties, which produced the then surprising date for the early appearance of an agricultural community at Jericho in the early seventh millennium B.c. Just before his death he was in process of inaugurating, with the aid of a grant from the Department of Scientific and Industrial Research, a big programme of research into sea-level and soil evidence for climatio fluctuations in the Quaternary period. His last book, The History of Domesticated Animals, was published earlier this year (Nature, 198, $45 ; 1963)$.

Zeuner's work and example must have a lasting effect on the study of the past in its scientific aspects. Many archæologists owe their introduction to the scientific connexions of their subject to him. He was an excellent toacher, with an enthusiasm for all branches of natural history which he communicated to all who listened to him, whether in his class-room or in the field. Students from many parts of the world wero attracted to the Institute of Archæology by his reputation, and returned to their own lands equipped to apply his ideas to their own problems.

W. F. GRIMES

\section{Dr. Frank L. Howard}

Dr. Frank L. Howard, chief of the Pure Substances Section in the Analytical Chemistry Division of the National Bureau of Standards, U.S. Department of Commerce, died suddenly on October 15, at the age of fifty. He was a staff member of the Bureau for more than twentysix years.

Dr. Howard was born in Pueblo, Colorado, in 1913. He was educated at the University of Maryland, complet. 
ing a B.S. in chemistry in 1934 and a Ph.D. in organic chemistry in 1938. He joined the Bureau in 1937 and became leador of the group engaged in synthesis of hydrocarbons. During the Second World War ho pursuod research aimed at improving aviation petrol. Following the War he turned his attention to the study of jet fuel and the phenomena of combustion. He was appointed acting chief of the Engine Fuels Section in 1949, and during that same year was the recipient of the Commerce Department's Silver Medal for Meritorious Service. In
1951 he was appointed chief of the Engine Fuels Section, and remained in that post until 1960, when he was appointed chief of the Pure Substances Section.

Dr. Howard's special fields of interest covered synthesis and purification of organic compounds, petroloum and fuel technology, combustion of fuels, distillation, and automotive antifreezes. $\mathrm{He}$ was author and co-author of many technical publications.

Dr. Howard is survived by his wife, two daughters and three sons.

\section{NEWS and VIEWS}

\section{Shell's Thornton Research Centre:}

Dr. T. M. Sugden, F.R.S.

Dr. T. M. SUGDEN has been appointed research director, Thornton Research Centre, Chester. Dr. C. B. Davies will continue to be director, Thornton Research Centre. The Thornton Laboratories are the largest of the five research laboratories operated by "Shell" Research, Ltd., in the United Kingdom. The work of the Thornton Laboratories is concerned with basic and applied research related to oil products. Dr. Sugden has been a reader in physical chemistry in the University of Cambridge. In this capacity he has been responsible for a major contribution to high-temperature chemistry by the development of flame photometric techniques for studying controlled traces of metallic elements and their compounds in flame gases. These techniques proved to be extraordinarily powerful, allowing the development of methods of measuring the stability of many simple compounds of metallic elements at high temperatures, of investigating new types of chemiluminescent reactions, and of determining rate constants for the reactions by which free radicals recombine after their production by chain-type processes.

Some five years ago, Dr. Sugden and his collaborators developed a mass spectrometer capable of sampling ions directly from flame gases. Many interesting species, some positively and some negatively charged, were shown to be associated with the flames of hydrogen and hydrocarbons, with and without metallic additives. Apart from being of great interest to students of chemical kineties, these results have a practical importance in rocket and magnetohydrodynamies technology. All Dr. Sugden's work has been characterized by determining the essential chemical features of complicated reacting systems and submitting them to quantitative examination by new methods.

\section{The Prix Jecker :}

Dr. Léo Marion, F.R.S.

Dr. Lro Marion, vice-president (scientifie) of the National Research Council, Canada, has been awarded the Prix Jecker by the Academy of Sciences. Paris, for his work on the structure of alkaloids. Dr. Marion was born in Ottawa. He gained an honours B.Sc. in 1926 and an M.Se. in 1927 from Queen's University and a Ph.D. degree from McGill University in 1929. The same year he began his career with the National Research Council of Canada, continuing in the field of organic chemistry. principally alkaloids, on which he carried out his postdoctorate work at the University of Vienna in 1934-35. Sinco 1947, Dr. Marion has served as editor-in-chief of the Canadian Journals of Research and, from 1952 until 1963, as editor of the Canadian Journal of Chemistry. $\mathrm{He}$ also serves on the editorial board of other scientific journals. He became head of the organic chemistry section of the Division of Chemistry in 1943, director of the Division of Pure Chemistry in 1952, senior director in 1960, and vice-president (scientific) of the National Research Council in 1963. Dr. Marion has many honours to his name, including fellowships of the Royal Society of London, the Royal Society of Canada, the Chemical Institute of Canada (of which he is a past-president), l'Association Canadienne-Française pour l'Âvancement des Sciences, and the Chemical Society of Great Britain, and membership of the American Chemical Society. Other honours for his contributions to the field of alkaloid chemistry include the Médaille Léo Pariseau of l'Association Canadienne-Française pour l'Avancement des Sciences, the Palladium Medal of the Chemical Institute of Canada, and the Gold Medal of the Professional Institute of the Public Service of Canada.

Founded in 1851, the Prix Jecker has been awarded, since 1857, to the author of the most useful work on organic chemistry, or to the chemist whose collective works have contributed most to the progress of organic chemistry. The recipient receives a monetary award of 6,500 French francs (1,300 dollars).

\section{Geography in the School of Oriental Studies (Univer- sity of London): \\ Prof. C. A. Fisher}

Prof. C. A. Fisher, head of the Department of Geography in the University of Sheffield since October 1959. has been appointed to the nowly created chair of geography in the School of Oriental Studies in the University of London. A graduate of the University of Cambridge, he first developed special interests in the geography of south-east Asia and far-eastern regions during the Second World War, when he was on active service in Malaya and, later, from 1942 until 1945, a prisoner of war in Japanese-controlled Thailand. These regional interests he has since developed; he has published numerous papers in various journals on aspects of the regional and political geography of eastern Asia and was a joint editor of the text, "Geographical Essays on British Tropical Lands". More recently, in a volume of some eight hundrod pages, he has contributed a major work on the social and political geography of south-east Asia, scheduled for publication in January 1964. In 1962 he led the British delogation of geographers attending the regional conference on south-east Asia, organized by the International Geographical Union at Kuala Lumpur. In 1961 he visited Japan in an extended tour, at the invitation of the Japanese Foreign Office, and in 1962 he was appointed as the first director of the Centre of Japanese Studies now attached to the University of Sheffield.

\section{The Defence (Transfer of Functions) Bill}

The Dofence (Transfer of Functions) Bill, which received its second reading in the House of Commons on November 21, is intended to implement the proposals of the White Paper published in July to establish a unified Ministry of Defence. Although in moving the second reading $\mathrm{Mr}_{\mathrm{r}}$. P. Thorneycroft, the Minister of Defence. emphasized the importance he attached in the new organization to having scientists built in the adminis- 